\title{
PENGARUH METODE GROUP INVESTIGATION TERHADAP HASIL BELAJAR SISWA PADA MUATAN MATERI PPKN DI KELAS V SDN 2 KALIJAGA
}

\section{Ferianto Zuhdi, Khairunnisa, Ilham Syahrul Jiwandono}

Program Studi Pendidikan Guru Sekolah Dasar, FKIP Universitas Mataram, J1. Majapahit no. 62, Mataram, Indonesia ilhamjiwandono@unram.ac.id

\begin{abstract}
One of the factors that impact the unsuccessfulness of studying PPKn in schools is the use of a learning model that is still less innovative. Teachers tend to use the old method that is teaching the materials using lectures, questions and answers, then giving the student assignments. As a result, students feel bored, passive, less interested in learning, which decrease students' learning outcomes. Group Investigation can be used as an alternative that will encourage students to be more active in learning with groups. This study aims to determine the effect of Group Investigation on students' learning outcomes in studying PPKn in the fifth grade student at SDN 2 Kalijaga academic year 2020/2021. This research is experimental research with Quasi Experimental Design type Nonequivalent Control Group Design. Population of this research was the fifth grade students of SDN 2 Kalijaga in academic year 2020/2021 consisting of two classes. The total number of the population was 45 people, all of them were chosen as the sample, where V/A as the experimental class and V/B as the control class. The researcher conducted observation and test to collect the required data. The result from the observation of applying Group Investigation in teaching indicate "fantastic" category with an percentage of $93.18 \%$ at the first meeting and $95.45 \%$ at the second meeting. The results showed that the score of student learning outcomes after being given treatment using Group Investigation was higher than before treatment. This is indicated by their pre-test score that is 50. After being given treatment their score increased become 86.81 in the post-test. Based on the results of hypothesis testing of independent samples $t$ test using SPSS 16.0 showed that the value of tcount equal to (2.742 and 2.727) > table (0.294) for students' achievement and significance level signify (Sig. 2-tailed) $0.009<0.05$. So that, it can be concluded that $H_{0}$ is rejected and Ha is accepted. It means that there is a positive effect of Group Investigation on the students' learning outcomes in studying PPKn at grade V students of SDN 2 Kalijaga in the academic year 2020/2021.
\end{abstract}

Keyword: Group Investigation method, Effect, Learning Outcomes, PPKn materials

\begin{abstract}
Abstrak
Salah satu faktor yang menyebabkan kurang berhasilnya proses pembelajaran PPKn di sekolah adalah penggunaan model pembelajaran yang masih kurang inovatif. Guru cenderung menggunakan metode lama, yaitu penyampaian materi pembalajaran menggunakan ceramah, Tanya jawab, dan penugasan. Akibatnya siswa merasa bosan, pasif, kurang tertarik untuk belajar sehingga menyebabkan rendahnya hasil belajar siswa. Model pembelajaran Group Investigation dapat dijadikan alternatif yang akan mendorong siswa agar lebih aktif dalam belajar secara berkelompok. Penelitian ini bertujuan untuk mengetahui pengaruh model pembelajaran kooperatif Tipe Group Investigation Terhadap Hasil Belajar Siswa Pada Muatan Materi PPKn di Kelas V SDN 2 Kalijaga Tahun Ajaran 2020/2021. Jenis penelitian ini adalah penelitian eksperimen dengan kategori Quasi Eksperimental Design tipe Nonequivalent Control Group Design. Populasi pada penelitian ini yaitu seluruh siswa kelas V SDN 2 Kalijaga Tahun pelajaran 2020/2021 sebanyak 45 siswa. Sedangkan sampel pada penelitian ini yaitu kelas V/A sebagai kelas eksperimen dan kelas V/B sebagai kelas kontrol. Teknik pengumpulan data menggunakan observasi dan tes hasil belajar. Data hasil observasi keterlaksanaan model pembelajaran tipe Group Investigation termasuk dalam kategori "sangat tinggi" dengan persentase nilai 93,18\% pada pertemuan pertama dan 95,45\% pada pertemuan ke dua. Hasil penelitian menunjukkan nilai rata-rata hasil belajar siswa setelah diberi perlakuan dengan menggunakan metode Group investigation lebih tinggi dibandingkan sebelum diberi perlakuan. Hal ini dapat dilihat dari rata-rata hasil belajar sebelum diberi perlakuan, yakni 50 pada pre-test, Setelah diberi perlakuan ratarata hasil belajar siswa meningkat, yakni 86,81 pada post-test. Berdasarkan hasil Uji hipotesis dengan perhitungan menggunakan uji independent samples t test melalui SPSS 16.0 menunjukkan bahwa, nilai thitung sebesar $(2,742$ dan 2,727) > $t_{\text {tabel }}(0,294)$ untuk hasil belajar siswa dan taraf signifikansi (Sig. 2-tailed) 0,009 <0,05. Maka dapat disimpulkan bahwa $H_{0}$ ditolak dan Ha diterima. Artinya ada pengaruh yang positif pendekatan metode Group Investigation terhadap hasil belajar PPKn siswa kelas V SDN 2 Kalijaga tahun pelajaran 2020/2021.
\end{abstract}

Kata kunci: Metode Group Investigation, Pengaruh, Hasil belajar, Muatan Materi PPKn

Program Studi Pendidikan Guru Madrasah Ibtidaiyah STAI Al-Azhar Menganti Gresik, Indonesia

Available online on: http://jurnal.stai-alazharmenganti.ac.id/index.php/ZAHRA 


\section{Pendahuluan}

Pada era millennial ini, pendidikan merupakan kebutuhan dasar setiap individu dalam rangka mempersiapkan sumber daya manusia yang berkarakter dan mampu bersaing terhadap kemajuan Ilmu Pengetahuan dan Teknologi (IPTEK). Dalam hal ini Pendidikan harus mampu memberikan pemahaman tentang belajar kepada siswanya. Belajar adalah perubahan tingkah laku secara relatif permanen dan secara potensial terjadi sebagai hasil dari praktik atau penguatan (reinforced practice) yang dilandasi untuk mencapai tujuan tertentu (Nurhasanah, Ilham Syahrul Jiwandono, 2020). Generasi yang kompeten dapat dicetak melalui pendidikan yang perlu ditanamkan sejak usia dasar. Pada Pendidikan di sekolah dasar peserta didik diharapkan mampu membuka wawasannya dan memegang peranan penting untuk meningkatkan kualitas dalam hidup bermasyarakat berupa pengembangan sikap, pengetahuan, dan keterampilan dasar. Salah satu mata pelajaran yang mampu membuka wawasan siswa dalam hidup bermasyarakat adalah Pendidikan Pancasila dan Kewarganeggaraan atau disingkat PPKn. PPKn merupakan mata pelajaran yang mengharapkan siswa berperan aktif dan kreatif dalam pembelajaran sehingga dapat diterapkan dalam kehidupan berbangsa dan bernegara.

Menurut Susanto (2012) PPKn adalah mata pelajaran yang digunakan sebagai wahana untuk mengembangkan dan melestarikan nilai luhur dan moral yang berakar pada budaya bangsa Indonesia. Dengan pendidikan kewarganegaraan ini diharapkan mampu membina dan mengembangkan siswa agar menjadi warga negara yang baik. Tujuan dari Pendidikan Pancasila dan Kewarganegaraan dapat di wujudkan dengan adanya pemahaman konsep terhadap muatan materi PPKn di sekolah. Pemahaman konsep merupakan kemampuan dasar yang harus dimiliki agar siswa mampu mengaitkan materi yang diajarkan dengan fenomena nyata dilingkungan sehingga siswa dikatakan dapat memahami materi-materi yang diajarkan apabila siswa kritis terhadap materi dan mampu menerapkan konsep tersebut kedalam kehidupan nyata. Hal ini diperkuat oleh pendapat yang dikutip dari Lipset (Sobirin Malian \& Suparman marzuki, 2003) mata pelajaran PPKn merupakan pelajaran yang menitikberatkan pada pembentukan karakter dan kesadaran pribadi pada setiap warga negaranya agar mampu melaksanakan hak-hak dan kewajibannya sebagai warga negara.

Hasil studi pendahuluan di kelas V SDN 2 Kalijaga yang terletak di Kecamatan Aikmel Kabupaten Lombok Timur, NTB, diperoleh informasi bahwa hasil belajar siswa pada materi PPKn masih kurang yang dilihat dari nilai hasil belajar ujian pertengahan semester 
mata pelajaran PPKn dikelas VA adalah 68 sedangkan kelas VB adalah 69. Hal tersebut menandakan bahwa hasil belajar siswa masih jauh dari nilai Kriteria Ketuntasan Minimum siswa yang diharapkan yaitu 75. Salah satu faktor yang menyebabkan rendahnya hasil belajar siswa dikarenakan kurangnya keterlibatan siswa dalam kegiatan pembelajaran yang lebih berpusat pada guru. Berdasarkan hasil wawancara dengan guru PPKn dan observasi kelas yang dilakukan pada tanggal 5 Oktober 2020, pada pelaksanaan pembelajaran PPKn, siswa cenderung pasif, banyak mendengarkan materi yang disampaikan guru tanpa adanya timbal balik, tak jarang banyak ditemukan siswa membuat gaduh, terlebih tidak adanya daya tarik dalam penyampaian materi dikarenakan guru menggunakan model pembelajaran yang monoton. Pembelajaran PPKn di sekolah dasar pada umumnya masih belum efektif dimana pembelajaran masih berpusat pada guru dan model pembelajaran yang cenderung menekankan peserta didik untuk lebih menghafal materi dan tentunya mengakibatkan peserta didik kurang memahami serta berdampak pada hasil belajar peserta didik bahkan kurang mampu dalam mengimplementasikan materi pembelajaran yang diberikan guru (Novita Rukmala Dewi, Khairunnisa, 2020). Kualitas pembelajaran tersebut dapat diperbaiki dengan menerapkan metode yang tepat sehingga mampu meningkatkan minat siswa dalam belajar guna mencapai hasil belajar yang maksimal.

Kegiatan pembelajaran memerlukan keaktifan belajar berupa, partisipasi dan komunikasi interaktif antara guru dan siswa (Nurfatimah et al., 2020). Sehubungan dengan hal tersebut guru dapat menggunakan model pembelajaran yang sangat beragam, salah satunya adalah diskusi kelompok (cooperative learning). Cooperative learning salah satu strategi pembelajaran yang melibatkan peran siswa secara aktif bekerjasama dalam mencapai tujuan Bersama. Dengan pembelajaran kooperatif peserta didik akan lebih mudah menemukan dan memahami konsep-konsep yang sulit apabila mereka dapat mendiskusikan masalah-masalah tersebut dengan temannya. Sehingga adanya peran guru tidak merupakan satu-satunya sebagai narasumber pembelajaran. Salah satu strategi pembelajaran yang dapat digunakan adalah strategi pembelajaran kooperatif tipe Group Investigation (GI). Strategi pembelajaran kooperatif tipe Group Investigation (GI) yaitu suatu strategi pelajaran yang menekankan pada proses keterlibatan siswa secara penuh untuk dapat menemukan sendiri materi yang dipelajari. Dari hasil penelitian Setianingsih (2018), Mahasiswa Universitas Lampung dengan judul "Pengaruh Model Pembelajaran Kooperatif Tipe Group Investigation Terhadap Hasil Belajar Subtema Indahnya Persatuan Dan Kesatuan Negeriku Siswa Kelas IV SD Negeri 8 Metro Timur" menunjukkan bahwa keberhasilan dari penerapan pembelajaran 
kooperatif dengan metode Group Investigation dipengaruhi oleh faktor-faktor yang kompleks, diantaranya: (1) pembelajaran berpusat pada siswa, (2) pembelajaran yang dilakukan membuat suasana saling bekerjasama dan berinteraksi antar siswa dalam kelompok tanpa memandang latar belakang, (3) siswa dilatih untuk memiliki kemampuan yang baik dalam berkomunikasi, (4) adanya motivasi yang mendorong siswa agar aktif dalam proses belajar mulai dari tahap pertama sampai tahap akhir pembelajaran.

Sehubungan dengan hal tersebut, maka sebagai seorang guru perlu mengadakan perbaikan-perbaikan yang berorientasi pada proses belajar mengajar menuju arah yang lebih baik, yaitu dengan menggunakan strategi yang lebih tepat agar terciptanya sebuah pembelajaran yang aktif, kreatif dan efektif serta menyenangkan. Guru mempunyai tanggung jawab melihat segala sesuatu yang terjadi dalam kelas untuk membantu proses perkembangan siswa (Afianti et al., 2020). Perkembangan zaman serta teknologi menuntut pendidik untuk mengembangkan keterampilannya dalam mengajar (Jiwandono, 2020). Salah satu strategi yang bisa digunakan untuk mengatasi permasalahan yang dihadapi tersebut yaitu dengan penerapan strategi pembelajaran kooperatif tipe Group Investigation (GI) dalam membantu mempebaiki hasil belajar siswa pada pembelajaran PKn, sehingga perlu diadakan penelitian eksperimen untuk membuktikan bahwa dengan adanya penerapan strategi pembelajaran kooperatif tipe Group Investigation (GI) dapat berpengaruh terhadap hasil belajar siswa kelas V SDN 2 Kalijaga Kecamatan Aikmel Kabupaten Lombok Timur semester ganjil tahun pelajaran 2020/2021. Berdasarkan penejlaskan diatas, penulis merumuskan masalah, apakah ada pengaruh Metode Group Investigation terhadap Hasil Belajar Siswa pada Muatan Materi PPKn di Kelas V SDN 2 Kalijaga?

\section{Metode Penelitian}

Jenis penelitian ini adalah penelitian kuantitatif dengan pendekatan eksperimen dengan desain non-equivalent control group design menggunakan 2 kelompok, yaitu kelompok eksperimen dan kelompok kontrol. Penelitian ini dilaksanakan pada bulan Desember 2020 semester ganjil tahun pelajaran 2020/2021 bertempat di SDN 2 Kalijaga yang beralamat di Jl.TGH. Muh. Shaleh Ahmad kalijaga, Dusun karang Luar Desa kalijaga kecamatan Aikmel Kabupaten Lombok Timur, NTB. Subjek dalam penelitian ini adalah siswa kelas V SDN 2 Kalijaga Kecamatan Aikmel. Sedangkan objek dalam penelitian ini adalah hasil belajar siswa. Populasi dalam penelitian ini adalah seluruh siswa kelas V SDN 2 kalijaga Tahun Pelajaran 2020/2021 dengan jumlah 45 siswa. Dan peneliti mengambil $100 \%$ jumlah populasi yang ada yaitu sebanyak 45 siswa sebagai sampel, dimana kelas V/A sebagai kelas eksperimen yang terdiri dari 22 siswa, dan kelas V/B sebagai kelas kontrol yang terdiri dari 23 siswa. 
Teknik pengumpulan data yang digunakan dalam penelitian ini yaitu, observasi untuk mengamati pelaksanaan pembelajaran menggunakan metode kooperatif tipe Group Investigation dan tes untuk mengetahui hasil belajar siswa yang terdiri dari 20 butir soal pilihan ganda. Sebelum digunakan untuk penelitian maka instrument tersebut di uji tingkat validitas dan tingkat reliabilitasnya terlebih dahulu. Adapun jenis-jenis pengujian validitas instrument yang digunakan dalam penelitian ini yakni: Validitas logis dilakukan dengan membandingkan antara isi instrumen dengan materi pelajaran yang telah diajarkan dinilai oleh expert judgement. Selain itu, peneliti juga menggunakan validitas empirik yaitu validitas yang dinyatakan berdasarkan hasil pengalaman, dimana instrument yang digunakan untuk penelitian di uji coba kan terlebih dahulu kepada siswa. Setelah tes diuji tingkat validitasnya, tes yang valid kemudian diukur tingkat reliabilitasnya.

Adapun prosedur dalam penelitian ini adalah menentukan kelas eksperimen dan kelas kontrol terlebih dahulu. Kemudian, menyusun kisi-kisi dan instrumen pengumpul data yang berupa tes pilihan jamak berjumlah 20 soal yang akan uji ahli berupa instrument observasi keterlaksanaan metode Group Investigation dan instrument tes kepada dosen ahli dan menguji coba instrumen tes kepada siswa kelas V di SDN 2 Kalijaga. Setelah didapatkan data hasil uji coba, maka dianalisis menggunakan bantuan SPSS untuk memperoleh instrument yang valid dan reliable. Apabila sudah didapatkan hasil uji validitas dan reliabilitas, maka dilaksanakan penelitian menggunakan metode Group Investigation di kelas eksperimen dan metode konvensional (ceramah,Tanya jawab, penugasan) di kelas kontrol kemudian mencari nilai rata-rata pretest dan posttest dari kedua kelas tersebut dan diolah menggunakan SPSS. Teknik analisis data yang digunakan dalam penelitian ini yaitu uji normalitas data, uji homogenitas, uji hipotesis dan uji keefektifan.

\section{Hasil Penelitian}

Dalam penelitian ini, peneliti menggunakan lembar penilaian pembelajaran model pembelajaran Group Investigation untuk melihat apakah pembelajaran yang dilaksanakan sudah sesuai dengan prosedur Group Investigation. Lembar penilaian ini terdiri dari 11 aspek penilaian dengan menggunakan rentang nilai 1-4. Adapun hasilnya dapat dilihat pada Tabel 1.

Tabel 1. Hasil Perhitungan Keterlaksanaan Metode Group Investigation

\begin{tabular}{|c|c|c|c|c|c|c|c|c|c|c|c|c|c|c|}
\hline \multirow{2}{*}{$\begin{array}{c}\text { Pertemuan } \\
\text { Ke- }\end{array}$} & \multicolumn{11}{|c|}{ Aspek } & \multirow[t]{2}{*}{ Nilai } & \multirow{2}{*}{$\begin{array}{c}\text { Persentase } \\
\text { Nilai }\end{array}$} & \multirow[t]{2}{*}{ Kriteria } \\
\hline & $\mathrm{A}$ & $\mathrm{B}$ & $\mathrm{C}$ & $\mathrm{D}$ & $\mathrm{E}$ & $\mathrm{F}$ & $G$ & $\mathrm{H}$ & I & $\mathbf{J}$ & $\mathrm{K}$ & & & \\
\hline I & 3 & 4 & 4 & 4 & 4 & 4 & 4 & 3 & 3 & 4 & 4 & 41 & $93,18 \%$ & $\begin{array}{l}\text { Sangat } \\
\text { Tinggi }\end{array}$ \\
\hline II & 4 & 3 & 4 & 4 & 4 & 4 & 3 & 4 & 4 & 4 & 4 & 42 & $95,45 \%$ & $\begin{array}{l}\text { Sangat } \\
\text { Tinggi }\end{array}$ \\
\hline
\end{tabular}

Berdasarkan tabel di atas, dapat diketahui bahwa pada pertemuan ke- I dan Pertemuan ke- II pelaksanaan pembelajaran model pembelajaran kooperatif tipe Group Investigation, diperoleh nilai pelaksanaan pembelajaran sebesar 93,18\% dan 95,45\%. Semua aspek yang menggambarkan karakteristik dari model pembelajaran kooperatif tipe Group Investigation yang meliputi apersepsi, 
menjelaskan materi pelajaran, pembagian tim dan penjelasan tugas tim, siswa mengerjakan tugas secara tim, guru mengawasi kerja tim dan memberikan kesempatan kepada siswa untuk bertanya, perwakilan tiap tim mempresentasikan hasil diskusinya, tim lain memberikan tanggapan, guru bersama siswa membuat kesimpulan, guru memberikan kuis dan menjelaskan cara mengerjakannya, guru mengevaluasi hasil kerja individu dan guru memberikan penghargaan sudah terlaksana dengan baik dengan kriteria "sangat tinggi".

Setelah pembelajaran dilaksanakan, selanjutnya menghitung hasil belajar siswa. Hasil belajar siswa berupa hasil tes awal (pretest) dan tes akhir (posttest).

Tabel 2. Data Hasil Belajar Belajar Siswa Kelas Eksperimen dan Siswa Kelas Kontrol

\begin{tabular}{lccccc}
\hline \multicolumn{1}{c}{ Kelas } & $\begin{array}{c}\text { Jumlah siswa } \\
(\mathbf{N})\end{array}$ & Tes & $\begin{array}{c}\text { Nilai } \\
\text { Tertinggi }\end{array}$ & $\begin{array}{c}\text { Nilai } \\
\text { Terendah }\end{array}$ & Rata-rata \\
\hline Eksperimen & 22 & Pretest & 85 & 30 & 50 \\
& & Posttest & 100 & 70 & 86,81 \\
Kontrol & 23 & Pretest & 85 & 25 & 57,39 \\
& & Posttest & 95 & 70 & 80,21 \\
\hline
\end{tabular}

Berdasarkan tabel diatas, dapat diketahui bahwa rata-rata nilai tes awal (pretest) untuk kelas eksperimen sebesar 50 dengan skor minimal 30 dan skor maksimal 85. Sedangkan kelas control, diperoleh nilai rata-rata pretest sebesar 57,39 dengan nilai teringgi 85 dan nilai terendah 25 . Sehingga bisa dikatakan bahwa hasil pre-test kelas eksperimen dan kelas kontrol memiliki kemampuan yang tidak jauh berbeda. Dari data tersebut juga terlihat bahwa nilai posttest siswa kelas eksperimen setelah diberikan perlakuan berupa penggunaan model pembelajaran kooperatif tipe Group Investigation mendapat nilai tinggi dibandingkan dengan hasil belajar kelas kontrol yang tidak diberikan perlakuan dengan model pembelajaran kooperatif tipe Group Investigation. Selain itu, nilai rata-rata siswa kelas eksprimen setelah diberikan perlakuan lebih tinggi, yaitu 86,81 dibandingkan dengan nilai rata-rata kelas kontrol yang diajarkan menggunakan metode konvensional (ceramah, Tanya jawab, dan penugasan), yaitu 80,21. Berdasarkan hasil tersebut, dapat disimpulkan bahwa ada perbedaan antara rata-rata nilai siswa kelas eksperimen dan kelas kontrol setelah diberikan perlakuan yang berbeda.

Analisis statistik data hasil penelitian meliputi uji prasyarat instrumen dan uji prasyarat analisis agar bisa melakukan analisis akhir (uji hipotesis). Pada uji prasyarat instrument dilakukan uji validitas dan uji reliabilitas. Berdasarkan hasil uji validitas logis dari expert judgement instrument yang digunakan sudah valid sesuai revisi. Dan berdasarkan uji validitas empirik dari 45 siswa dengan $\mathrm{r}$ tabel 0,294 diperoleh $\mathrm{r}$ hitung lebih besar dari 0,294 sehingga sebanyak 20 butir soal dinyatakan valid. Dan untuk uji reliabilitas instrument menggunakan SPSS model Split-Half dengan koefisien reliabilitas lebih dari 0,6 yaitu yaitu 0,831>0,6 dan nilai $\mathrm{r}$ hitung > $\mathrm{r}$ tabel yaitu 0,831 >0,29 sehingga dapat disimpulkan bahwa instrument tes yang digunakan reliable. Setelah diperoleh data hasil belajar siswa maka dilakukan uji prasyarat analisis meliputi uji normalitas data, uji homogenitas posttest kelas eksperimen dan kelas control. Berdasarkan uji normalitas menggunakan SPSS diperoleh nilai signifikansi pada kolom kolmogorov smirnov pada kelas eksperimen 0,2 dan kelas kontrol 0,1, 
maka nilai signifikansinya lebih dari 0,05, dengan dasar pertimbangan jika nilai Signifikansinya > 0.05 maka dapat dikatakan data tersebut berdistribusi normal namun jika nilai Signifikansinya $<0.05$ maka data tersebut tidak terdistribusi normal. Berdasarkan data diolah SPSS diperoleh nilai sig. 0,2 > 0,05 dan sig. $0,1>0,05$, Sehingga dapat disimpulkan bahwa data hasil tes akhir kelas eksperimen dan kelas kontrol terdistribusi normal.

Selanjutnya dilakukan uji homogenitas menggunakan SPSS. Homogen atau tidaknya suatu data dapat dilihat dari nilai signifikansi dari kolom Levene Statistic. Melalui menu analyze - compare means - One-Way ANOVA. Jika nilai signifikansinya > 0,05, maka dapat dikatakan bahwa hasilnya homogen.

Tabel 3 Hasil Uji Homogenitas

Test of Homogeneity of Variances

Hasil Belajar Siswa

\begin{tabular}{rrrrr}
\hline Levene Statistic & df1 & \multicolumn{1}{c}{ df2 } & Sig. \\
\hline 1.612 & & 1 & 43 & .211 \\
\hline
\end{tabular}

Dari hasil perhitungan menggunakan SPSS 16.0 diatas diketahui nilai signifikansi dari kolom Levene Statistic menunjukan nilai signifikansi 0,211. Dengan nilai signifikansi 0,211 >0,05 maka dapat ditarik kesimpulan bahwa varians data kedua kelas tersebut homogen. Dengan demikian, maka salah satu syarat (tidak mutlak) dari uji independents sampel t test (uji hipotesis) sudah terpenuhi.

Untuk menentukan apakah hipotesis diterima atau ditolak maka dilakukan uji perbedaan dan uji keefektifan. Adapun hipotesis pada penelitian ini yakni, $\mathrm{H}_{\mathrm{a}}$ : Ada pengaruh yang positif pendekatan metode Group Investigation terhadap hasil belajar PPKn siswa kelas V SDN 2 Kalijaga tahun pelajaran 2020/2021 dan $\mathrm{H}_{0}$ : Tidak ada pengaruh yang positif pendekatan metode Group Investigation terhadap hasil belajar PPKn siswa kelas V SDN 2 Kalijaga tahun pelajaran 2020/2021. Berdasarkan uji hipotesis menggunakan SPSS dengan uji Independent Samples T Test dilihat dari kolom $t$ tes for equality of means diperoleh nilai $t_{\text {hitung }}$ sebesar $\left(2,742\right.$ dan 2,727) $>t_{\text {tabel }}(0,294)$ untuk hasil belajar siswa dan taraf signifikansi (Sig. 2-tailed) 0,009 < 0,05, jika mengacu pada ketentuan pengambilan keputusan uji hipotesis maka dapat disimpulkan bahwa $\mathrm{H}_{0}$ ditolak dan Ha diterima. Artinya ada pengaruh yang positif pendekatan metode Group Investigation terhadap hasil belajar PPKn siswa kelas V SDN 2 Kalijaga tahun pelajaran 2020/2021 yang dibuktikan dengan adanya perbedaan hasil belajar antara kelas eksperimen dan kontrol, dimana kelas eksperimen memiliki rata-rata nilai akhir yang lebih tinggi daripada kelas kontrol.

Berdasarkan uji keefektifan menggunakan program SPSS dengan uji pihak kanan (one sample $t$ test). Kriteria pengambilan keputusan uji kesamaan rata-rata yaitu, jika signifikansi $<0,05$, maka $\mathrm{Ha}$ diterima (Trihendradi, 2013). Dari hasil penghitungan statistik hasil belajar kelas eksperimen dan kontrol tersebut didapatkan signifikansi 0,000 $<0,05$ maka $\mathrm{Ha}$ diterima. Jadi, bisa disimpulkan bahwa hasil belajar siswa pada pembelajaran dengan menggunakan model Group Investigation lebih efektif dari pada pembelajaran menggunakan model konvensional, yaitu 
pembelajaran menggunakan metode ceramah, Tanya jawab dan penugasan. Dari hasil kedua uji tersebut dapat disimpulkan bahwa hipotesis $\mathrm{H}_{\mathrm{a}}$ : Ada pengaruh yang positif pendekatan metode Group Investigation terhadap hasil belajar PPKn siswa kelas V SDN 2 Kalijaga tahun pelajaran 2020/2021 diterima dan hipotesis $\mathrm{H}_{0}$ : Tidak ada pengaruh yang positif pendekatan metode Group Investigation terhadap hasil belajar PPKn siswa kelas V SDN 2 Kalijaga tahun pelajaran 2020/2021 ditolak.

\section{Diskusi}

Penelitian ini telah dilaksanakan di SDN 2 Kalijaga dimulai dari tanggal 7 Desember 2020 sampai dengan 12 Desember 2020. Sebelum melakukan penelitian, peneliti menentukan kelas eksperimen dan kelas kontrol terlebih dahulu. Dalam penelitian ini kelas V/A merupakan kelas eksperimen dengan jumlah 22 siswa dan kelas V/B merupakan kelas kontrol dengan jumlah siswa sebanyak 23 orang. Kemudian, peneliti menyusun kisi-kisi dan instrumen pengumpul data yang berupa tes pilihan jamak berjumlah 20 soal. Soal test tersebut sudah dikonsultasikan kepada dosen pembimbing 1 dan 2 dan telah di uji ahli melalui expert judgement oleh ahli dan dinyatakan telah valid sesuai dengan revisi.

Peneliti kemudian melakukan uji coba instrument tes tersebut kepada siswa kelas V di SDN 2 Kalijaga. Pengolahan data hasil uji coba melalui SPSS bahwa instrument tes mendapat hasil yang valid dan reliable untuk seluruh butir soal dengan jumlah 20 butir. Dari hasil tersebut, selanjutnya peneliti sukses melaksanakan penelitian menggunakan metode Group Investigation di kelas eksperimen dan metode konvensional (ceramah, Tanya jawab, penugasan) di kelas kontrol. Dari hasil penelitian yang telah dilaksanakan, data diolah dan dianalisis menggunakan bantuan SPSS, dan diperoleh nilai rata-rata posttest kelas eksperimen mengalami peningkatan yang lebih tinggi dibandingkan kelas kontrol. Data hasil belajar siswa terdistribusi normal dan bersifat homogen. Uji hipotesis menunjukkan bahwa ada pengaruh positif penerapan metode Group Investigation terhadap hasil belajar PPKn siswa kelas V SDN 2 Kalijaga tahun ajaran 2020/2021.

Temuan penelitian menunjukkan adanya perbedaan antara hasil belajar siswa yang diperoleh dengan menerapkan model Group Investigation dan menerapkan konvensional (ceramah, tanya jawab, dan penugasan). Pada pelaksanaannya, siswa begitu menghayati materi diskusi, ketika ditemukan masalah yang tidak mampu dipecahkan oleh rekan diskusi, siswa secara aktif mencari informasi kepada guru tentang hal yang tidak dipahami. Guru tidak langsung menanggapi dengan memberikan jawaban langsung, melainkan memberikan gambaran kepada siswa selanjutnya siswa yang menentukan poin yang dijelaskan oleh guru. Suprijono (2009) mengemukakan bahwa penggunaan model group investigation, setiap kelompok akan bekerja melakukan investigasi sesuai dengan masalah yang mereka pilih. Proses tersebut membuat siswa saling berbagi pengetahuan, sehingga hasil belajar siswa menjadi tinggi. Terbukti hasil belajar pada kelas eksperimen memperoleh rata-rata 86,82 dan kelas kontrol memperoleh rata-rata 80,22. 
Model pembelajaran kooperatif tipe group investigation dapat memberikan dampak positif dalam meningkatkan prestasi belajar siswa. Model ini juga melatih siswa untuk memiliki kemampuan yang baik dalam berkomunikasi dan mengemukakan pendapatnya. Memotivasi dan mendorong siswa agar aktif dalam proses belajar (Kurniasih, 2015). Hasil penelitian membuktikan bahwa hasil belajar siswa yang menerapkan model Group Investigation berbeda dengan hasil siswa yang menerapkan model konvensional (ceramah, tanya jawab, dan penugasan) yakni dilihat dari rata-rata nilai hasil belajar antara kelas eksperimen dan kelas kontrol. Rata-rata hasil belajar akhir siswa pada kelas eksperimen 86,82 sedangkan di kelas kontrol 80,22. Pada pelaksanaan model Group Investigation, pembelajaran dimulai dari minat dan keinginan siswa terhadap materi yang ingin mereka pelajari yang kemudian dikerjakan secara berkelompok. Proses ini akan membuat siswa mencari sendiri materi yang sedang dipelajarinya, sehingga pembelajaran menjadi bermakna bagi siswa sehingga akan meningkatkan hasil belajar siswa dan membuatnya bertahan lama. Instrumen penelitian yang digunakan dalam penelitian ini berupa soal posttest yang telah teruji validitas, reliabilitasnya.

Dapat disimpulkan bahwa nilai hasil belajar siswa dalam pembelajaran Group Investigation lebih tinggi dibandingkan dengan pembelajaran di kelas kontrol yang tidak menerapkan model Group Investigation. Pelaksanaan pembelajaran di kelas eksperimen dengan menerapkan model Group Investigation mampu memberikan hasil belajar yang baik. Pembelajaran di kelas kontrol yang menggunakan model konvensional (ceramah, Tanya jawab, dan penugasan) berbeda dengan kelas eksperimen yang menggunakan model Group Investigation. Pada pembelajaran dengan model konvesional terkesan kurang mementingkan proses belajar siswa dan hanya terpaku pada hasil belajar. Siswa secara pasif mendengarkan ceramah guru yang merupakan satu-satunya sumber informasi. Siswa tidak mencari sendiri pengetahuannya melalui proses berfikir dan berdiskusi. Siswa pun malas memperhatikan atau tidak berminat ketika pembelajaran berlangsung, karena pembelajaran berlangsung monoton dan tidak melibatkan siswa. Melalui model Group Investigation, siswa dikondisikan untuk belajar secara aktif, baik secara fisik, mental dan emosional. Keaktifan secara fisik nampak saat siswa menyampaikan pendapat saat diskusi, menyampaikan hasil diskusi di depan umum, dan melihat unjuk kerja siswa lain. Keaktifan secara mental nampak saat siswa berfikir kritis untuk mencari informasi bersama kelompoknya. Keaktifan secara emosional nampak pada semangat siswa saat mengikuti pembelajaran.

Melalui pembelajaran PPKn materi keputusan bersama yang menggunakan metode $G I$ siswa saling bertukar pikiran dan menghargai pendapat kelompok pada saat diskusi dan menyimak dengan baik saat kelompok lain sedang presentasi, secara tidak langsung siswa telah mengimplementasikan makna keputusan bersama. Sebagaimana yang dikemukakan oleh Winataputra (2009) warga negara yang baik adalah yang mengetahui, menyadari, dan melaksanakan hak dan kewajibannya sebagai warga Negara. Model Group Investigation menstimulus siswa untuk menemukan sendiri pengetahuannya melalui proses berpikir kritis dalam diskusi kelompok. Sehingga 
siswa tidak sekedar menghafal materi yang didapatnya. Melainkan siswa juga paham akan materi yang diperolehnya karena materi tersebut diperoleh oleh siswa sendiri melalui belajar bersama menemukan jawaban melalui investigasi kelompok.

Berdasarkan data hasil penelitian yang sudah dijabarkan di atas, dapat disimpulkan bahwa penerapan model Group Investigation memiliki pengaruh terhadap hasil belajar siswa kelas V pada muatan materi PPKn, yang dibuktikan dengan meningkatnya nilai rata-rata hasil belajar siswa. Merujuk pada beberapa kelebihan dari model pembelajaran kooperatif tipe Group Investigation yang cukup rasional berpengaruhnya model tersebut terhadap hasil belajar pada mata pelajaran PPKn, pada materi "Keputusan Bersama" sehingga di dapat hasil perhitungan hipotesis penelitian diterima yang berarti ada pengaruh yang signifikan atas penggunaan model pembelajaran kooperatif tipe Group Investigation terhadap hasi belajar PPKn siswa Kelas V SDN 2 Kalijaga Tahun Pelajaran 2020/2021.

\section{Simpulan}

Berdasarkan hasil penelitian eksperimen yang telah dilaksanakan di SDN 2 Kalijaga pada muatan materi PPKn siswa kelas V dengan menerapkan model Group Investigation menunjukkan bahwa hasil uji hipotesis hasil belajar siswa dengan perhitungan menggunakan uji independent sample $t$ test ditandai dengan nilai signifikansinya $0,009<0,05$. Mengacu pada ketentuan pengambilan keputusan uji hipotesis, maka dapat disimpulkan bahwa $\mathrm{H}_{0}$ ditolak dan Ha diterima. Jadi bisa disimpulkan bahwa ada perbedaan hasil belajar siswa pada pembelajaran menggunakan model Group Investigation dengan pembelajaran menggunakan model konvensional (ceramah, Tanya jawab, dan penugasan). Dan berdasarkan hasil uji paired sample t test diketahui nilai signifikansi Pair 1 untuk pre-test dan post-test kelas kontrol adalah 0,000 <0,05, dan nilai signifikansi Pair 2 untuk pre-test dan post-test kelas eksperimen juga 0,000 < 0,05 maka dapat disimpulkan bahwa ada pengaruh positif penerapan metode pembelajaran kooperatif tipe Group Investigation terhadap hasil belajar PPKn siswa kelas V SDN 2 Kalijaga tahun ajaran 2020/2021, yang ditandai dengan meningkatnya nilai ratarata hasil belajar siswa. Hasil uji keefektifan hasil belajar siswa dengan perhitungan menggunakan uji pihak kanan (one sample t test) pada program SPSS versi 21. Dari hasil penghitungan statistik hasil belajar kelas eksperimen dan kontrol didapatkan nilai signifikansi $0,000<0,05$ maka $\mathrm{Ha}$ diterima. Jadi bisa disimpulkan bahwa hasil belajar siswa pada pembelajaran dengan menggunakan model Group Investigation lebih efektif dari pada pembelajaran menggunakan model konvensional (ceramah, Tanya jawab, dan penugasan).

Berdasarkan simpulan yang telah dipaparkan, bahwa model pembelajaran kooperatif tipe Group Investigation terbukti berpengaruh positif terhadap hasil belajar siswa pada muatan materi PPKn kelas V SDN 2 Kalijaga, maka disarankan bagi Guru agar melakukan variasi dalam penggunaan model pembelajaran kooperatif sehingga dapat menciptakan suasana pembelajaran yang menyenangkan bagi siswa dan hendaknya guru mulai menerapkan model pembelajaran kooperatif tipe Group Investigation, karena lebih efektif dalam meningkatkan hasil belajar dan keaktifan siswa 
dibandingkan dengan menggunakan model pembelajaran konvensional (ceramah, Tanya jawab, dan penugasan). Sebelum menggunakan model pembelajaran kooperatif tipe Group Investigation, sebaiknya guru merencanakan pembelajaran yang akan dilaksanakan dengan baik, sehingga pada pelaksanaannya dapat berlangsung sesuai dengan apa yang diharapkan dan mengetahui dahulu karakteristik siswa yang diajar agar nantinya tidak terjadi penggerombolan (geng) dalam berkelompok sehingga kemampuan tiap kelompok merata dan kegiatan pembelajaran berkelompok dapat berlangsung sesuai dengan yang diharapkan.

\section{Daftar Pustaka}

Afianti, D., Witono, A. H., \& Jiwandono, I. S. (2020). Identifikasi Kesulitan Guru Dalam Pengelolaan Kelas Di Sdn 7 Woja Kecamatan Woja Kabupaten Dompu. Jurnal Elementaria Edukasia, 3(2), 203-213.

Agus Suprijono. (2009). Cooperative Learning Teori dan Aplikasi PAIKEM. Pustaka Pelajar.

Ahmad Susanto. (2012). Teori Belajar dan Pembelajaran di Sekolah Dasar. Karisma Putra Utama.

Etin Solihatin. (2007). Cooperative Learning Analisis Model Pembelajaran IPS. Bumi Aksara.

Jiwandono, I. S. (2020). Analisis Metode Pembelajaran Komunikatif Untuk Ppkn Jenjang Sekolah Dasar. Elementary School Education Journal), 4(1), 9-19.

Kurniasih, I. dan B. S. (2015). Ragam Pengembangan Model Pembelajaran. Kata Pena.

Novita Rukmala Dewi, Khairunnisa, I. S. J. (2020). Jurnal Inovasi Penelitian. Jurnal Inovasi Penelitian, 1(7), 1465-1474.

Nurfatimah, Affandi, L. H., \& Jiwandono, I. S. (2020). Analisis Keaktifan Belajar Siswa Kelas Tinggi Di SDN 07 Sila Pada Masa Pandemi Covid-19. Jurnal Ilmiah Profesi Pendidikan, 5(2), 145-154.

Nurhasanah, Ilham Syahrul Jiwandono, M. A. (2020). Pengaruh Pemberian Reward Dan Punishment Terhadap Motivasi Belajar Siswa Pada Muatan Ppkn Kelas Iv Sdn Pemepek Kecamatan Pringgarata Tahun Ajaran 20202021. Jurnal Inovasi Penelitian, 1(7), 1289-1296. https://doi.org/https://doi.org/10.47492/jip.v1i7.229

Setianingsih. (2018). Pengaruh Model Pembelajaran Kooperatif Tipe Group Investigation Terhadap Hasil Belajar Subtema Indahnya Persatuan Dan Kesatuan Negeriku Siswa Kelas IV SD Negeri 8 Metro Timur. Universitas Lampung.

Sobirin Malian \& Suparman marzuki. (2003). Pendidikan kewarganegaraan dan Hak Asasi Manusia. UII Press.

Winataputra, U. S. (2009). Pembelajaran PKn di SD. Universitas Terbuka. 